\title{
A rupture of the aneurysm of the sinus of Valsalva in a patient with history of aortic coarctation surgery - a case report
}

\author{
Tomáš Kolomazník, Vladimír Kaučák, Kamil Novobílský, Radim Kryza
}

Department of Cardiology, Municipal Hospital Ostrava, Ostrava

ARTICLE INFO

Article history:

Submitted: 5. 9. 2018

Accepted: 4. 12. 2018

Available online: 26. 9. 2019

\section{Klíčová slova:}

Aneurysma na mozkové tepně

Koarktace aorty

Ruptura Valsalvova sinu

\section{Keywords:}

Cerebral aneurysm

Coarctacion of aorta

Valsalva sinus rupture

\section{SOUHRN}

Popisujeme vzácný prípad 31leté ženy s dyspnoe vyvolané rupturou aneurysmatu na Valsalvově sinu. Ve věku čtyř let u ní byla provedena operace koarktace aorty a ve věku 25 let prodělala subarachnoidální krvácení po ruptuře aneurysmatu na mozkové tepně.

(C) 2019, ČKS

\section{ABSTRACT}

We present a rare case of a 31-year-old woman with dyspnoea, caused by a rupture of the Valsalva sinus. As a 4-year-old, she underwent a surgery of aortic coarctation, as a 25-year-old, she suffered from subarachnoid haemorrhage from a ruptured cerebral aneurysm.

\section{Introduction}

A sinus of Valsalva is the aortic root area between the aortic valve annulus and the sinotubular ridge. Typically, the left and right sinuses contain each their respective coronary artery ostium, while the posterior sinus is noncoronary. The function of the sinuses lies in allowing the aortic valve opening during systole without an occlusion of the coronary artery ostia. ${ }^{1}$

The ruptures of the sinus of Valsalva typically occur between 20 and 40 years of age, they are quite rare among paediatric or elderly patients. They are also much more frequent in males than in women (the estimated ratio is 4 : 1) and in the Asians than in the Western population. ${ }^{1}$ The rupture of the right coronary sinus is the most common (approx. $75 \%$ of cases), followed by that of non-coronary sinus (approx. 20\%) and the rupture of the left coronary sinus $(5 \%)^{2}$

The anatomical location of the aneurysm and the direction of the rupture also largely determine the clinical consequences of the rupture. Most frequently, the right ventricle is involved and the rupture of the right coronary or non-coronary sinuses typically create a communication between the aorta, the right ventricular outflow tract or the aorta and the right atrium. The rupture of the left coronary sinus is on the other hand usually less significant, resulting in an communication to the left atrium and left ventricular outflow tract. ${ }^{1}$

The incidence is largely unknown. The estimated rate of the sinus of Valsalva aneurysms (SVA), which are the most common cause of the rupture, is approximately 0.1 to $3.5 \%$ of all congenital cardiac defects and probably around $0.09 \%$ of the general population; however, only a fraction of these aneurysms ever progress into a rupture. SVA itself can be completely asymptomatic up to the moment of the rupture, although in rare cases they can lead to cardiac arrhythmias, atrial fibrillation or even a complete heart block. ${ }^{3}$

SVA are usually congenital, though they can also be acquired (e.g. through infections weakening the elastic tissue such as syphilis, tuberculosis or bacterial endocarditis, through atherosclerotic damage or through injury). ${ }^{2}$ The 


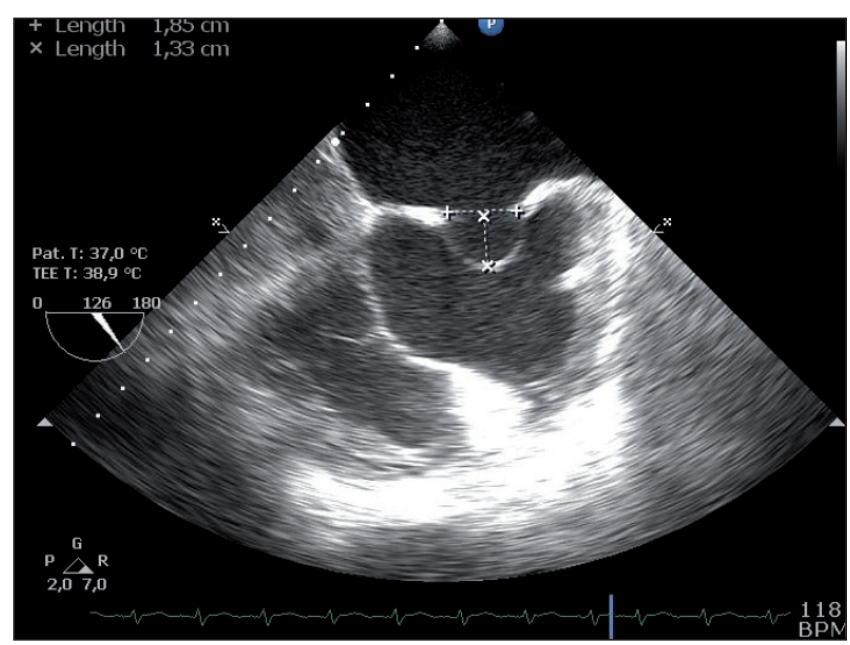

Fig. 1 - Atrial septal aneurysm

congenital problems can be associated with other congenital heart defects, such as bicuspid aortic valve or aortic regurgitation. ${ }^{3,4}$

Symptoms of RSVA can include substernal chest pain, abdominal pain, and mild to severe dyspnoea. In many cases, patients may experience symptoms of an acute heart failure, cardiac tamponade, and even sudden cardiac death. On auscultation, a holosystolic murmur can be typically detected. ${ }^{1,4}$

The principal role in the correct diagnosis is, however, played by imaging methods, the principal of which (for detection of RSVA) is the transoesophageal echocardiography (TEE), although thoracic CT or MRI can also be helpful for detection of additional anomalies. ${ }^{3}$

Although multiple case reports where percutaneous endovascular treatment was performed have been published, ${ }^{5-7}$ surgical treatment with a pericardial patch remains the usual method of choice for treatment of RSVA.

\section{Case report}

A 31-year-old woman was admitted to our Cardiology ward due to a dyspnoea provoked by the slightest exertion. The onset of symptoms (cough and dyspnoea) was sudden and the patient originally (three weeks before admission) attended her general practitioner who treated her unsuccessfully for a respiratory infection; only after the failure of his treatment, he referred the patient to our clinic.

Despite the fact, that the patient had a history of congenital vascular disease - as a 4-year-old, she had undergone an aortic coarctation surgery, in time the admission she had no regular follow-up by a cardiologist. When she was 25 years old, she suffered from a subarachnoid haemorrhage due to a ruptured cerebral aneurysm.

On admission, she was breathing normally, with a mild sinus tachycardia (100/min normal blood pressure, otherwise normal findings on physical exam and EKG). Laboratory results revealed a mildly elevated BNP, D-dimers and leukocytosis (Table 1).

On TTE, which quality of imaging was modified by presence of tachycardia, the ejection systolic function

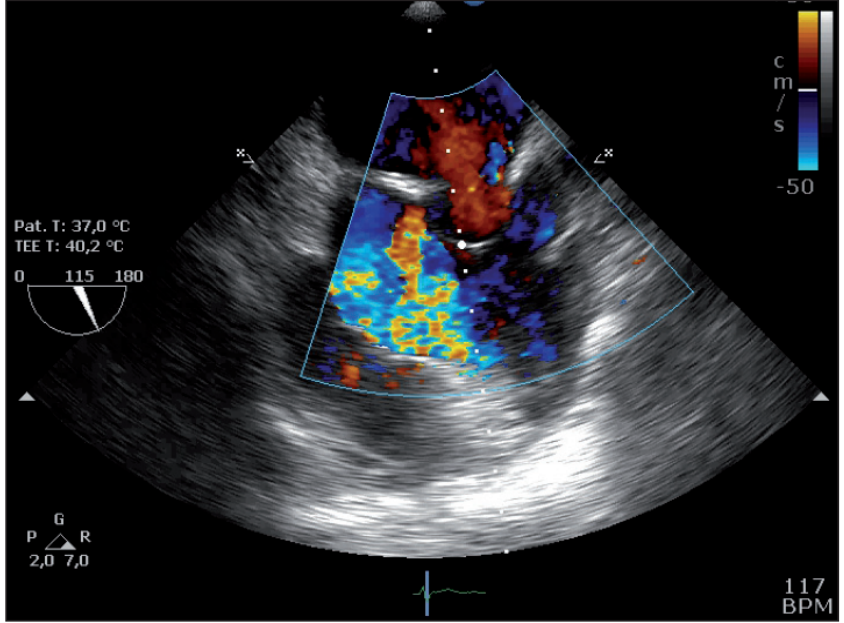

Fig. 2 - Atrial septal aneurysm in colour doppler without L-P shunt.

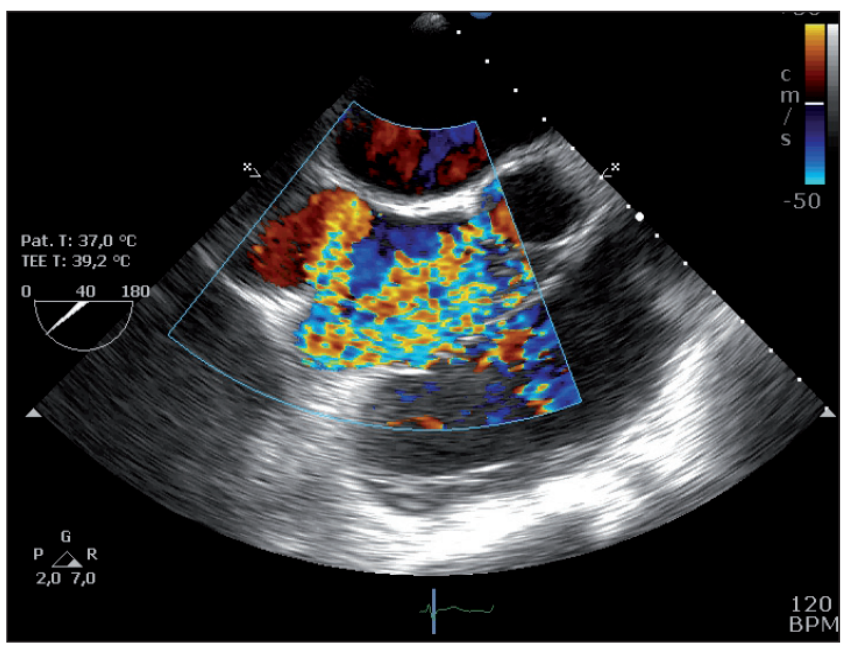

Fig. 3 - A rupture of the sinus of Valsalva in the colour doppler view.

of both ventricles was normal. The examination also revealed a mild dilatation of the right ventricle, suspicion of severe tricuspid insufficiency, atrial septal aneurysm with suspected L-P shunt and small bilateral pleural effusions.

To rule out pulmonary embolism, CT angiography was performed, with no pulmonary emboli found, no signs of recoarctation, no pathological abnormality in the pulmonary parenchyma. However, simultaneous filling of both right and left ventricle was detected along with the suspicion of L-P shunt.

TEE was subsequently performed, revealing a rupture of the Valsalva sinus, along with a bicuspid aortic valve with moderate aortic insufficiency and an atrial septal aneurysm without L-P shunt (Figs 1-3).

Table 1 - Abnormal laboratory findings

\begin{tabular}{|l|l|l}
\hline & Value & Reference cut-off \\
\hline D-dimers & $431 \mu \mathrm{g} / \mathrm{l}$ & $0-243 \mu \mathrm{g} / \mathrm{l}$ \\
\hline BNP & $429 \mathrm{pg} / \mathrm{ml}$ & $0-150 \mathrm{pg} / \mathrm{ml}$ \\
\hline Leukocytes & $12.9 \times 10^{9}$ & $3.8-10 \times 10^{9}$ \\
\hline
\end{tabular}


Due to the past history of congenital disease, a genetic evaluation of tissue disorders (Marphan, Ehler-Danlos syndrome) was also performed, the results were negative.

The patient was transferred to the cardiothoracic surgery department where a reconstruction of the Valsalva sinus with a pericardial patch was performed without any complications. The post-surgery transthoracic echocardiography (TTE) showed a normal systolic function of both ventricles along with a moderate aortal insufficiency. Due to the fact that the other disorders (bicuspidal valve, atrial septal aneurysm) were asymptomatic and due to the young age of the patient, those other disorders were not treated.

\section{Discussion}

A rupture of the sinus of Valsalva (RSVA) is a rare condition with a variety of manifestations ranging from an asymptomatic murmur to cardiogenic shock and sudden cardiac death. ${ }^{8}$ As the SVA itself is often congenital, the presence of other congenital problems is not uncommon. Potential associated pathologies include the bicuspid aortal valve and aortic regurgitation, ${ }^{9}$ both of which were also present in our case.

The interesting point in our case is the presence of aortic coarctation in the past, which has been surgically treated 20 years before the development of the RSVA. In the literature, we can find several reports of the combined presence of aortic coarctation and RSVA, 10,11 these are, however, extremely rare occurrences that can be only found in about $1-2 \%$ of RSVA cases. ${ }^{11}$ In general, the coarctation of aorta is mostly associated with other cardiovascular defects. In a post-mortem study in infants and young individuals, a bicuspid aortic valve, which has been also present in our case, was the most frequent anomaly associated with aortic coarctation in patients who died at the age older than 6 months (present in approx. $65 \%$ of those patients), followed by abnormal communications including septal defects $(55 \%) .^{12}$ Another defect frequently associated with the coarctation of aorta is an intracranial aneurysm, which is present in approx. $10 \%$ of patients with this affliction. ${ }^{13}$ In our patient, all these anomalies were, currently or in the past, present and associated with the aortic coarctation; it is therefore necessary to bear in mind that any patient with aortic coarctation in the personal history is likely to have also other anomalies and, if such patient presents to the cardiology clinic with any problem, to perform a thorough examination of all possible associated abnormalities.

\section{Summary}

In all, we would like to draw attention of the readers to this rare condition. If a patient presents whose only problem is dyspnoea and the remaining initial clinical examination does not reveal anything substantial, it can still represent a patient with a ruptured sinus of Valsalva. TTE and especially TEE are crucial for the correct diagnosis. It is particularly necessary to think of the sinus of Valsalva rupture if the patient is known to have some other congenital heart defects, such as, in our case, the coarctation of the aorta, which is known to be frequently associated with other abnormalities.

\section{References}

1. Weinreich M, Yu PJ, Trost B. Sinus of valsalva aneurysms: review of the literature and an update on management. Clin Cardiol 2015;38:185-189.

2. Cao LB, Hannon D, Movahed A. Noncoronary sinus of Valsalva rupture into the right atrium with a coexisting perimembranous ventricular septal defect. World J Clin Cases 2013;1:146-148.

3. Bass D, Bhimji SS. Aneurysm, Sinus Of Valsalva. In: StatPearls. 2018, StatPearls Publishing Publishing LLC.: Treasure Island (FL).

4. Tipoo Sultan FA, Basir N, Fatimi S. Aneurysm of sinus of Valsalva. J Coll Physicians Surg Pak 2011;21:173-175.

5. Gioia G, Zheng J, Ray A, et al. Perforated Sinus of Valsalva (PSOV) aneurysm closure with a muscular VSD occluder. Cardiovasc Revasc Med 2014;15:165-170.

6. Kuriakose EM, Bhatla P, McElhinney DB. Comparison of reported outcomes with percutaneous versus surgical closure of ruptured sinus of Valsalva aneurysm. Am J Cardiol 2015;115:392-398.

7. Wilson W, Emmanuel Y, Uren N, et al. Percutaneous closure of ruptured sinus of Valsalva aneurysms using a retrograde approach without formation of an arteriovenous loop. Eurolntervention 2015;10:e1.

8. Shah RP, Ding ZP, Ng AS, et al. A ten-year review of ruptured sinus of Valsalva: clinico-pathological and echo-Doppler features. Singapore Med J 2001;42:473-476.

9. Contino M, Mangini A, Romagnoni $C$, et al. Commissural repositioning in bicuspid aortic valve repair with Valsalva graft. J Vis Surg 2018;4:70.

10. Ouali S, Kortas C, Brockmeier K, et al. Adult aortic coarctation discovered incidentally after the rupture of sinus of Valsalva aneurysm: combined surgical and interventional approach. Interact Cardiovasc Thorac Surg 2011;13:688-690.

11. Pahwa JS, Verma G, Phadke MS, et al. Simultaneous transcatheter closure of ruptured sinus of Valsalva aneurysm and stent implantation for aortic coarctation. Indian Heart J 2015;67(Suppl 3):S81-S84.

12. Becker AE, Becker MJ, Edwards JE. Anomalies associated with coarctation of aorta: particular reference to infancy. Circulation 1970;41:1067-1075.

13. Connolly HM, Huston J, 3rd, Brown Jr. RD, et al. Intracranial aneurysms in patients with coarctation of the aorta: a prospective magnetic resonance angiographic study of 100 patients. Mayo Clin Proc 2003;78:1491-1499. 